\title{
Comparative Analysis of the Maritime Venture Risk and the Cost of Averting a Fatality in the Republic of Croatia
}

\section{Komparativna analiza rizika u pomorstvu i cijene sprečavanja pogibelji u Republici Hrvatskoj}

\author{
Dario Medić \\ University of Split \\ Faculty of Maritime Studies \\ e-mail:dmedic@pfst.hr
}

\author{
Zvonimir Lušić \\ University of Split \\ Faculty of Maritime Studies \\ e-mail: zvonimir.lusic@pfst.hr
}

\author{
Rino Bošnjak \\ University of Split \\ Faculty of Maritime Studies \\ e-mail: rino.bosnjak@pfst.hr
}

DOI 10.17818/NM/2019/2.3 UDK 656.61:368.2(497.5)

Preliminary communication / Prethodno priopćenje Paper accepted / Rukopis primljen: 11. 3. 2019.

\begin{abstract}
Summary
Given the fact that every maritime venture is exposed to continuous risks, it is necessary to create a hierarchic structure of its predictors and to manage them efficiently. In view of that, the International Maritime Organization (IMO) suggests the possibility of risk management through the Formal Safety Assessment (FSA). The key element in the implementation of this method is to determine the optimum point of investment in risk reduction with the purpose of achieving the balance between the costs of protective measures and the profit. Although it may be inappropriate to discuss the price of a human life, it is nevertheless possible to calculate it by formal mathematical procedures through the Cost of Averting a Fatality (CAF) and the Implied Cost of Averting a Fatality (ICAF). This methodology has allowed to produce - and to present in this paper - the above values for the Republic of Croatia for the very first time. In addition, by using the $\chi 2$ test, it has been possible to examine the relations between the observed actions (foundering, collision / impact, flooding, fire, disabled and adrift, man overboard) and the period (years 2006-2017). The results clearly show a statistically relevant dependence $(\varkappa 2(88)=143,17 ; p<0,001)$ among the observed categories, which probably results from various implementation dynamics of the risk reduction measures that are performed in Croatia on a yearly basis. The results obtained by this research can provide important additional guidelines for the optimisation of the risk management model.
\end{abstract}

\section{Sažetak}

Uzimajući u obzir činjenicu da je svaki plovidbeni pothvat izložen kontinuiranom riziku, nužno je na odgovarajući način hijerarhijski strukturirati njegove prediktore te njima optimalno upravljati. U skladusa spomenutim, IMO (eng. International Maritime Organization) nudi mogućnost upravljanja rizikom uz pomoć Formalne procjene sigurnosti (eng. Formal Safety Assessment - FSA). Pritom je ključan element implementacije te metode određivanja optimalne točke ulaganja u smanjenje rizika s ciljem postizanja ravnoteže troškova zaštitnih mjera i dobiti. lako je neprikladno govoriti o cijeni ljudskog života, ona se formalnim matematičkim postupcima izračunava putem cijene sprečavanja pogibelji (eng. Cost of Averting a Fatality-CAF), te pretpostavljene cijene sprječavanja pogibelji (engl. Implied Cost of Averting a Fatality - ICAF). U radu su korištenjem prikladne metodologije po prvi put izračunate spomenute vrijednosti za Republiku Hrvatsku. Dodatno, korištenjem \2 testa, ispitana je zavisnost broja promatranih akcija (tone, sudar/udar, naplavljivanje, požar, onesposobljen i pluta, čovjek u moru) igodine (2006.-2017.). Rezultatijasno pokazuju postojanje statističkiznačajne zavisnosti $(\varkappa 2(49)=152,57 ;$; $<0,001)$ promatarnih kategorija, što je vjerojatno posljedica različitih implementacijskih dinamika mjera za smanjenje rizika koje se u Hrvatskoj provode na godišnjoj bazi. Rezultati ovog istraživanja mogu dati važne dodatne smjernice optimizaciji modela upravljanja rizikom.

\section{KEY WORDS}

risk management

Formal Safety Assessment

Cost of Averting a Fatality

\section{KLJUČNE RIJEČI \\ upravljanje rizikom formalna procjena sigurnosti cijena sprečavanja pogibelji}


available measures on time, in order to reduce the risk and avoid an accident.[8] However, although on-board crews are trained and ready to respond efficiently and on time, the reallife cases prove that human error is still the most common cause of sea accidents.[4][5][6] According to the International Maritime Organization (IMO), the risk is defined as the probability that an undesired event will take place, followed by a series of the resulting consequences occurring in real time. [8] The consequences include threats to human life and health, and damage to property and environment. It is necessary to manage the risk efficiently in order to minimise it. This is the very reason for implementing the Formal Safety Assessment (FSA) as a risk management method recommended by IMO. The FSA methodology offers the acceptable risk measures for the loss of human life on board, as well as the ways of calculating its value. This will be further discussed in the paper, with a particular reference to the Republic of Croatia.[12]

\section{ANALYSIS OF THE PROCESS OF RISK MANAGEMENT / Analiza procesa upravljanja rizikom}

The Formal Safety Assessment (FSA) is a risk management method recommended by the International Maritime Organization (IMO). Initially it had been proposed by the UK's Marine Coastguard Agency (MCA), relying on the already accepted system of risk analysis applied in the offshore industry.[9] FSA is a process aimed at increasing safety at sea through preserving human life and natural environment. It allows a continuous analysis of the benefits and assessment of costs of risk reduction measures. It consists of five essential stages:[18]

1. Identification of hazard,

2. Analysis of risk,

3. Risk control measures,

4. Assessment of cost benefit, and

5. Conclusions and recommendations (Figure 1).

The first step comprises the analytical and creative techniques for hazard identification and monitoring. By using analytical elements, previous experience and background data (lists of hazards, analytic data, dangerous substances, etc.) are taken into consideration. The use of creative elements ensures that the process is proactive and not limited only to the hazards that have occurred so far. It consists of structured group reviews of experts from relevant areas, who try to identify the causes and consequences of maritime hazards and accidents. The hazards are then arranged by priorities in order to discard the scenarios that are deemed to be less relevant. Therefore, this stage results in a list of hazards and scenarios ranked by priorities, given their causes, consequences and the above mentioned risk assessment. Hazards can now be grouped as very probable or frequent, reasonably probable, hazards of remote probability, and hazards of extremely remote probability (Table1). The method of assessing the risks presented in Table 2 can be applied depending on the risk category.

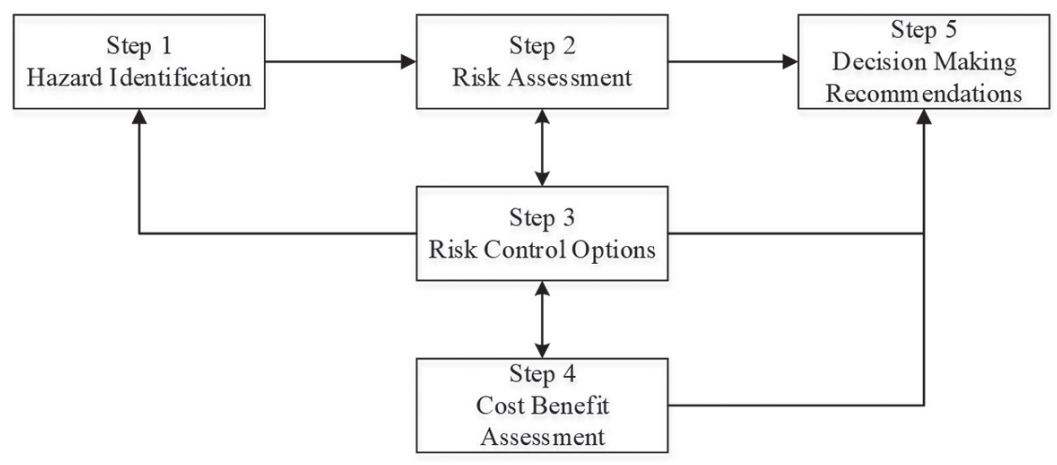

Source: Guidelines for Formal Safety Assessment (FSA) for the Use in the IMO Rule-Making Process, MSC/Circ.1023, MEPC/Circ.392, IMO, London, UK, 2002, p. 15.

Figure 1 Process of risk management / Flow chart of the FSA methodology Slika 1. Proces upravljanja rizikom / Dijagram toka FSA metodologije

Table 1 Example of the hazard probability categorisation Tablica 1. Primjeri kategorizacije vjerojatnosti nastupa opasnosti

\begin{tabular}{|c|c|c|c|c|}
\hline Hazard probability category & Very probable (frequent) & Reasonably probable & Remote probability & Extremely remote probability \\
\hline Type of event & $\begin{array}{l}\text { Likely to occur once in six } \\
\text { months }\end{array}$ & $\begin{array}{l}\text { Likely to occur once in } \\
\text { five years }\end{array}$ & $\begin{array}{l}\text { Likely to occur once in } \\
\text { the lifetime }\end{array}$ & $\begin{array}{l}\text { Less than } 1 \% \\
\text { events per person to occur } \\
\text { during their lifetime }\end{array}$ \\
\hline
\end{tabular}

Source: Hess, M.; Kos, S.; Njegovan. M.: Procjena i kontrola operativnih rizika na brodu u skladu s ISM pravilnikom / Assessment and control of operational risks on board in line with ISM rulebook, in: Pomorstvo, University of Rijeka - Faculty of Maritime Studies, Rijeka, 2011 , p. 411. 
Table 2 Risk assessment according to the hazard probability category

Tablica 2. Procjena rizika ovisno o opasnosti

\begin{tabular}{|l|l|l|l|}
\hline Hazard probability & Level of hazard & & \\
\hline & Minor damage & Moderate damage & Major damage \\
\hline & VERY LOW RISK & VERY LOW RISK & HIGH RISK \\
\hline Very probable & VERY LOW RISK & MEDIUM RISK & VERY HIGH RISK \\
\hline Reasonably probable & LOW RISK & HIGH RISK & VERY HIGH RISK \\
\hline Remote probability & VERY HIGH RISK & VERY HIGH RISK \\
\hline Extremely remote probability & LOW RISK &
\end{tabular}

Source: Hess, M.; Kos, S.; Njegovan. M.: Procjena i kontrola operativnih rizika na brodu u skladu s ISM pravilnikom / Assessment and control of operational risks on board in line with ISM rulebook, in: Pomorstvo, University of Rijeka - Faculty of Maritime Studies, Rijeka, 2011, p. 411.

The second step - risk analysis - is aimed at a detail examination of all relevant scenarios (including causes and consequences) that are identified in the first stage, by means of construction and quantification methods. This stage results in the identification of the high-risk areas.

The third step in the FSA methodology implies the analysis and proposal of practical and effective Risk Control Options (RCOs) with the purpose of creating the risk control options that are able to deal with the existing and the newly identified risks. This step includes the following stages:[12]

1. focusing on risk areas needing control,

2. identifying potential RCOs,

3. evaluating the effectiveness of the RCOs in reducing risk by re-evaluating the Step 2, and

4. grouping RCOs into practical regulatory options.

The goal of the fourth step is to identify and compare benefits and costs associated with the implementation of each RCO identified and defined in the previous step (Step 3). A Cost Benefit Assessment (CBA) comprises the analysis of the detected risks and the associated RCOs, the CBA for each individual option, and the ranking of RCOs. There are several calculation indices which express the value of human life and cost-effectiveness in relation to safety of life, such as Gross Cost of Averting a Fatality (GCAF) and Net Cost of Averting a Fatality (NCAF).

The last step (Step 5) refers to defining all objective recommendations which should be presented to decision majers. The recommendations contain careful and detailed consideration and ranking of all hazards and their underlying causes, comparison and ranking of Risk Control Options in terms of the associated costs and benefits, and the identification of those RCOs which keep risks as low as reasonably practicable.

\section{ANALYSIS OF THE LOSS OF HUMAN LIFE RISK ACCEPTABILITY ON BOARD / Analiza prihvatljivosti rizika gubitka ljudskog života na brodu}

The analysis of measures and tolerability of risks deals with the cost effectiveness of these measures. This can be easily assessed in case of material risks, where a cost effective measure is the one whose value is greater than the value of an individual damage. Obviously, in case of human life or natural environment, the acceptability of investing in risk protection is hard to determine. However, the process can be facilitated by the guidelines developed and published by the UK governemnatal organisation Health and Safety Executive (HSE) whose main focus is the health and safety at work. The principle of ALARP (As Low As Reasonably Practicable) refers to a level of risk that is neither negligibly low nor intolerable high. ALARP is actually the attribute of a risk, for which further investment of resources for risk reduction is not justifiable. The principle has been approved by IMO and vaties according to the area of maritime shipping (Figure 2).Furthermore, the framework of FSA sets the following values of the human life risk acceptability:[10]

- Maximum tolerable fatality risk to crew members $-10^{-3}$ per year, - Maximum tolerable fatality risk to passengers $-10^{-4}$ per year, - Maximum tolerable fatality risk to third parties (people ashore) - 10-4per year, and

- Negligible risk-10-6 per year.

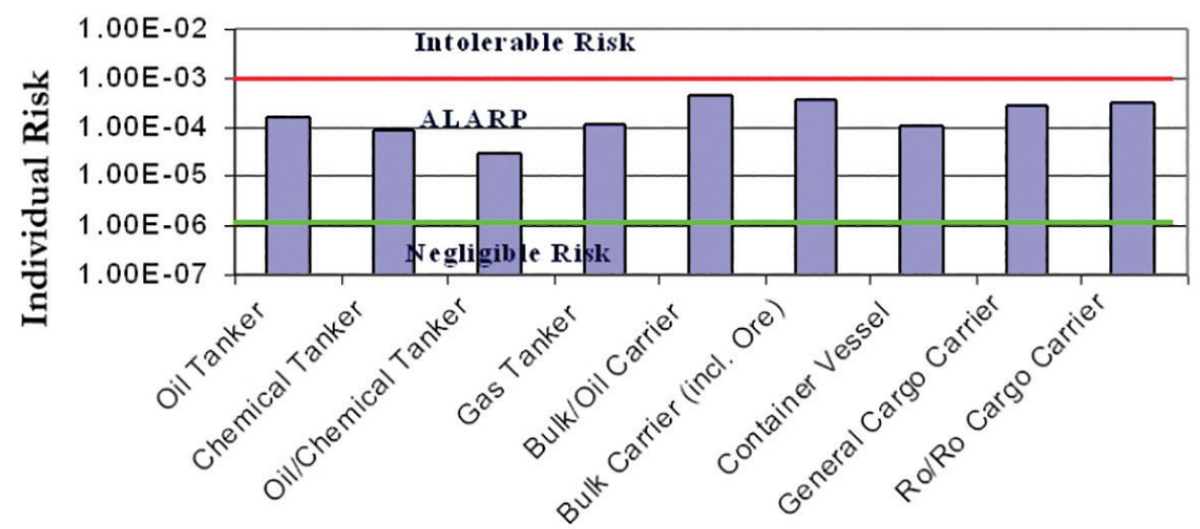

Source: Kontovas, C. A., Psaraftis, H. N.: Formal Safety Assessment: A Critical Review, Marine technology 46(1):45-59, 2009.

Figure 2 Individual fatality risk (per years) for crewmembers on board various types of ships, with the suggested criteria of the individual risk acceptability

Slika 2. Individualni rizik od pogibelji (godišnji) za posadu različitih vrsta brodova, prikazan s predloženim kriterijima prihvatljivosti individualnog rizika 
The analysis of maritime hazards and risks takes into account the categories of the Individual Risk (IR) and Societal Risk. The IR refers to the indivudual risk of death or injury at a given working location, while the Societal Risk refers to an average risk of accidents affecting many persons, i.e. the entire group that can be exposed to a hazard. The IR can be expressed as:[14]

$$
I R=F \cdot P \cdot E
$$

Where:

$\mathrm{F}$ - frequency of the undesirable event,

$\mathrm{P}$ - probability of accident for person $\mathrm{Y}$, and

$\mathrm{E}$ - fractional exposure of person $\mathrm{Y}$ to the given risk.

The assessment of the cost effectiveness of investing in the reduction of risk and the ranking of accidents are the issues affecting the assessment of the individual risk. The IMO recommends the following relations when creating a risk matrix: 1 fatality equals 10 cases of serious injuries, while 1 case of serious injuries equals 10 cases of minor injuries (Table 3 ).
The frequency index represents the relation between the lower number of accidents with serious consequences and the higher number of accidents with minor consequences (Table 4).

An analysis of Tables 3 and 4 results in the formula that is a preerquisite for creating a Risk matrix (Table 5):[13]

$$
R I=F I+S I
$$

Where:

$\mathrm{RI}$ - Risk index,

$\mathrm{FI}$ - Frequency index, and

SI - Severity index.

The risk matrix is a suitable means for ranking the risks, with the purpose of their cost-benefit assessment. However, practical use proves that the suggested matrix is not an ideal tool for risk ranking, because of errors that occur, for instance, due to the linear change in frequency of severity, unless the conditions and circumstances surrounding an accident have not been evaluated.

Table 3 Severity index

\begin{tabular}{|c|c|c|c|c|}
\hline \multicolumn{5}{|c|}{ Severity index (SI) } \\
\hline SI & SEVERITY & EFFECTS ON HUMAN SAFETY & EFFECTS ON SHIP & $\mathrm{S}$ (equivalent fatalities) \\
\hline 1 & Minor & Single or more minor injuries & Local equipment damage & 0.01 \\
\hline 2 & Significant & Multiple or severe injuries & Non-severe ship damage & 0.1 \\
\hline 3 & Severe & Single fatality or multiple severe injuries & Severe damage to ship & 1 \\
\hline 4 & Catastrophic & Multiple fatalities & Total loss & 10 \\
\hline
\end{tabular}

Tablica 3. Indeks posljedice

Source: Guidelines for Formal Safety Assessment (FSA) for Use in the IMO Rule-Making Process, MSC/Circ.1023, MEPC/Circ.392, IMO, London, UK, 2002 , p. 43.

Table 4 Frequency index

\begin{tabular}{|c|c|c|c|}
\hline \multicolumn{4}{|c|}{ Frequency index (FI) } \\
\hline $\mathrm{FI}$ & FREQUENCY & DEFINITION & $F$ (per ship per year) \\
\hline 7 & Frequent & Likely to occur once per month on one ship & 10 \\
\hline 5 & Reasonably probable & $\begin{array}{l}\text { Likely to occur once per year in a fleet of } 10 \text { ships, i.e. likely to occur a few } \\
\text { times during the ship's life }\end{array}$ & 0,1 \\
\hline 3 & Remote & $\begin{array}{l}\text { Likely to occur once per year in a fleet of 1,000 ships, i.e. likely to occur in the } \\
\text { total life of several similar ships }\end{array}$ & $10^{-3}$ \\
\hline 1 & Extremely remote & Likely to occur once in the lifetime ( 20 years) of a world fleet of 5,000 ships & $10^{-5}$ \\
\hline
\end{tabular}

Tablica 4. Indeks učestalosti

Source: Guidelines for Formal Safety Assessment (FSA) for Use in the IMO Rule-Making Process, MSC/Circ.1023, MEPC/Circ.392, IMO, London, UK, 2002, p. 43.

Table 5 Risk matrix

\begin{tabular}{|c|c|c|c|c|c|}
\hline \multicolumn{6}{|c|}{ Risk index (RI) } \\
\hline \multirow{3}{*}{$\mathrm{FI}$} & \multirow{3}{*}{ FREQUENCY } & \multicolumn{4}{|c|}{ SEVERITY (SI) } \\
\hline & & 1 & 2 & 3 & 4 \\
\hline & & Minor & Significant & Severe & Catastrophic \\
\hline 7 & Frequent & 8 & 9 & 10 & 11 \\
\hline 6 & & 7 & 8 & 9 & 10 \\
\hline 5 & Reasonably probable & 6 & 7 & 8 & 9 \\
\hline 4 & & 5 & 6 & 7 & 8 \\
\hline 3 & Remote & 4 & 5 & 6 & 7 \\
\hline 2 & & 3 & 4 & 5 & 6 \\
\hline 1 & Extremely remote & 2 & 3 & 4 & 5 \\
\hline
\end{tabular}

Tablica 5. Matrica rizika

Source: Guidelines for Formal Safety Assessment (FSA) for Use in the IMO Rule-Making Process, MSC/Circ.1023, MEPC/Circ.392, IMO, London, UK, 2002, p. 44. 
Societal risk is typically expressed as a FN-diagram or through the so-called Potential Loss of Life (PLL). The PLL is defined as the expected value of the number of fatalities per year. PLL is a type of risk integral, being a summation of risk as expressed by the product of consequence and frequency:[9]

$$
P L L=\sum_{N=1}^{N_{u}} N \cdot f_{N}=F_{1}\left(1+\sum_{N=1}^{N_{u}-1} \frac{1}{N+1}\right)=F_{1} \cdot \sum_{N=1}^{N_{u}} \frac{1}{N}
$$

Where:

$N$ - upper limit of fatalities in a single accident,

$f_{N}$ - frequency of accidents involving $N$ fatalities, and

$\mathrm{F}_{1}$ - frequency of fatalities involving one or more victims.

\section{COMPARATIVE ANALYSIS OF THE VALUE AND LOSS OF HUMAN LIFE ON BOARD / Komparativna analiza vrijednosti i gubitka ljudskog života na brodu}

\subsection{GCAF AND NCAF METHODOLOGIES / GCAF i NCAF metodologija}

The cost of preventing the loss of human life on board can be expressed as the gross and net values, i.e. as GCAF (Gross Cost of Averting a Fatality) and NCAF (Net Cost of Averting a Fatality). It is deemed that, in practise, the advantage should be given to GCAF as it depends heavily on the costs of fatality prevention. [7] NCAF also takes into account economic benefits from the Risk Control Options (RCOs) under consideration. This may be misused in some cases for pushing certain RCOs, by considering more economic benefits on preferred RCOs than on other RCOs. Here are the equations for GCAF and NCAF criteria:[10]

$$
\begin{gathered}
G C A F=\frac{\Delta C}{\Delta R} \\
N C A F=\frac{\Delta C-\Delta B}{\Delta R}
\end{gathered}
$$

Where:

$\Delta C=$ Expected cost of the RCO (per vessel),

$\Delta B=$ Economic benefit (per vessel) as the result of the applied RCO (may also include pollution prevention) and

$\Delta R=$ Risk reduction (per vessel), i.e. reduction of fatalities in accordance with the implemented measures.

There is the co-called 3-million-US-dollars criterion that is applied in all recent FSA analyses and cost-benefit assessments using RCOs.[10]According to this criterion, the preferred RCO must have GCAF and NCAF values less than 3 million US dollars. In this case, the NCAF formula is expressed as:[10]

$$
N C A F=\frac{\Delta C-\Delta B}{\Delta R}\langle \$ 3 m \Rightarrow \Delta C-\Delta B\langle \$ 3 m \cdot \Delta R
$$

Whereby the parameters $\Delta C, \Delta B$ and $\Delta R$ must meet the following relation:

$$
\Delta C\langle \$ 3 m \cdot \Delta R+\Delta B
$$

Furthermore, under equal conditions, the GCAF formula is:

$$
\Delta C\langle \$ 3 m \cdot \Delta R
$$

\subsection{ICAF / ICAF}

In recent years, the FSA analyses have been using the Implied Cost of Averting a Fatality (ICAF) which results from the Life Quality Index (LQI). The LQI is used for expressing the social, health, environment and economic dimensions of the quality of life at working conditions, and the formula expressing these values is:[3]

$$
L Q I=g^{w} \cdot e^{(1-w)}
$$

Where:

$\mathrm{g}$ - gross domestic product per resident,

e - average life expectancy, and

w - economically active part of lifetime.

In case the proposed RCO is accepted, the value of the ICAF is established. The latter can be defined as an optimum amount of funds to be invested in order to prevent a fatal accident. [1]These funds are larger in developed countries so that, for instance, they amount to around 5 million US dollars in the USA.

Where:

$$
\mathrm{ICAF}_{0}=\frac{\gamma \cdot \varepsilon}{4} \cdot \frac{1-\mathrm{w}}{\mathrm{w}}
$$

$\gamma$ - gross domestic product per resident per year,

$\varepsilon$ - average life expectancy, and

w - economically active part of lifetime (in developed countries: $W \approx 1 / 8$ ).

\section{CALCULATION OF THE GCAF, NCAF AND ICAF VALUES FOR THE REPUBLIC OF CROATIA / Izračun vrijednosti GCAF, NCAF i ICAF za Republiku Hrvatsku}

5.1. COMPARATIVE ANALYSIS OF THE MARITIME TRAFFIC AND MARITIME ACCIDENTS IN THE REPUBLIC OF CROATIA / Komparativna analiza pomorskog prometa i pomorskih nezgoda u Republici Hrvatskoj

Table 7 provides the data on maritime traffic (ship arrivals) over the period 2006 - 2017. It can be notices that the traffic of vessels increased from 223967 to 258670 , i.e. an increase of 34703 arrivals. Table 8 presents the causes and number of performed search and rescue operations over the same period of time. It can be noticed that there was a drop in performed SAR operations following the year 2011, but there was an increase in performed SAR operations after 2014, in accordance with an increased number of ships in the same period. Figure 3 combines the data from Tables 7 and 8 to show that the growth of SAR operations did not follow the growth of traffic proportionally (see Figure 3). In other words, after the year of 2011 the frequency of SAR actions decreased although the number of ship arrivals increased by 23000 , while increased traffic after 2014 influenced the increase in performed SAR actions.

Table 6 IMO cost effectiveness criteria for RCOs Tablica 6. IMO kriterij isplativosti mjera za sprečavanje nezgoda

\begin{tabular}{|l|c|c|}
\hline Criterion covering the risk of fatality, injuries and ill health & NCAF (million USD) & GCAF (million USD) \\
\hline Criterion covering only the risk of fatality & 3.0 & 3.0 \\
\hline Criterion covering only the risk of injuries and ill health & 1.5 & 1.5 \\
\hline
\end{tabular}

Source: Formal Safety Assessment, Risk evaluation, Submitted by the International Association of Classification Societies (IACS), MSC 78/19/2, IMO, London, UK, 2004, p. 10. 
Table 7 Flow of vessels in Croatia's seaports (arrivals)

Tablica 7. Promet brodova u morskim lukama RH, prispjeli brodovi

\begin{tabular}{|c|c|c|c|c|c|c|c|c|}
\hline \multirow{2}{*}{ Year } & \multicolumn{2}{|c|}{ Total } & \multicolumn{2}{|c|}{ National flag } & \multicolumn{2}{|c|}{ Foreign flag } & \multicolumn{2}{|c|}{ Vessels in nautical ports } \\
\hline & Vessels & GT,'000 & Vessels & GT, '000 & Vessels & GT, '000 & Permanently moored & Transit \\
\hline 2006 & 223967 & 247560 & 217636 & 192887 & 6331 & 54672 & 13794 & 211782 \\
\hline 2007 & 235489 & 267140 & 229005 & 204118 & 6484 & 63021 & 14099 & 220875 \\
\hline 2008 & 248539 & 285045 & 241184 & 214343 & 7355 & 70702 & 14665 & 217024 \\
\hline 2009 & 247547 & 278948 & 240990 & 210546 & 6557 & 68401 & 14801 & 203327 \\
\hline 2010 & 235841 & 291421 & 229327 & 214753 & 6514 & 76668 & 14431 & 206028 \\
\hline 2011 & 250918 & 296023 & 245266 & 217128 & 5652 & 78895 & 14286 & 188457 \\
\hline 2012 & 247571 & 287782 & 242767 & 210368 & 4804 & 77413 & 14396 & 181457 \\
\hline 2013 & 246939 & 299885 & 242122 & 215476 & 4817 & 84408 & 13735 & 182921 \\
\hline 2014 & 258670 & 294261 & 253990 & 221354 & 4680 & 72906 & 13793 & 181322 \\
\hline 2015 & 258670 & 294261 & 253990 & 221354 & 4680 & 72906 & 13399 & 182526 \\
\hline 2016 & 258670 & 294261 & 253990 & 221354 & 4680 & 72906 & 13422 & 198151 \\
\hline 2017 & 258670 & 294261 & 253990 & 221354 & 4680 & 72906 & 13433 & 201896 \\
\hline
\end{tabular}

Source: Croatian Bureau of Statistics, http://www.dzs.hr/

Table 8 Number of performed SAR operations Tablica 8. Broj poduzetih akcija traganja i spašavanja

\begin{tabular}{|c|c|c|c|c|c|c|c|c|c|c|}
\hline \multicolumn{11}{|c|}{ Action performed due to } \\
\hline & 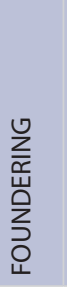 & 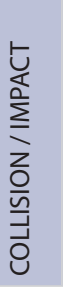 & 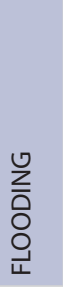 & 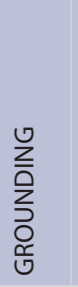 & 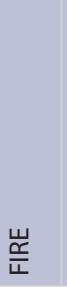 & 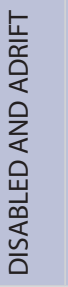 & 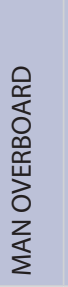 & 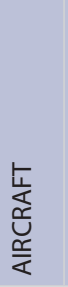 & 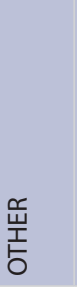 & 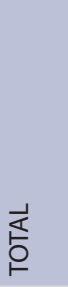 \\
\hline 2006 & 3 & 7 & 17 & 34 & 3 & 88 & 13 & - & 109 & 274 \\
\hline 2007 & 7 & 10 & 8 & 72 & 8 & 92 & 9 & - & 146 & 352 \\
\hline 2008 & 6 & 2 & 1 & 32 & 8 & 81 & 9 & 1 & 139 & 278 \\
\hline 2009 & 8 & 3 & 10 & 59 & 8 & 104 & 9 & - & 116 & 317 \\
\hline 2010 & 20 & 9 & 8 & 43 & 8 & 105 & 14 & - & 166 & 373 \\
\hline 2011 & 15 & 19 & 13 & 59 & 9 & 85 & 15 & - & 132 & 347 \\
\hline 2012 & 18 & 23 & 7 & 60 & 8 & 59 & 6 & - & 82 & 263 \\
\hline 2013 & 17 & 11 & 11 & 42 & 12 & 60 & 5 & - & 128 & 286 \\
\hline 2014 & 11 & 23 & 7 & 60 & 8 & 59 & 6 & - & 168 & 342 \\
\hline 2015 & 11 & 15 & 8 & 43 & 9 & 48 & 10 & - & 180 & 324 \\
\hline 2016 & 7 & 17 & 8 & 59 & 8 & 86 & 13 & - & 249 & 447 \\
\hline 2017 & 12 & 29 & 13 & 51 & 18 & 59 & 17 & - & 255 & 454 \\
\hline
\end{tabular}

Source: Ministry of the Sea, Transport and Infrastructure,http://www.mppi.hr/UserDocsImages/SAR\%20STAT\%201999-2008.pdf, http://www.mppi. hr/UserDocsImages/corr.MRCC\%20statistika\%201-1.-31-12_1420-1_15.pdf, http://www.mppi.hr/UserDocsImages/SAR\%20stat\%202015\%201.I.31.XII.\%2020-1_16.pdf,http://www.mppi.hr/UserDocsImages/MPPI\%20SAR\%201.I-31.XII-16\%20STATISTIKA\%2020-1_17.pdf, http://www.mppi.hr/ UserDocsImages/MMPI\%20SAR\%201.I-31.XII-17\%20STATISTIKA\%208-1_18.pdf 


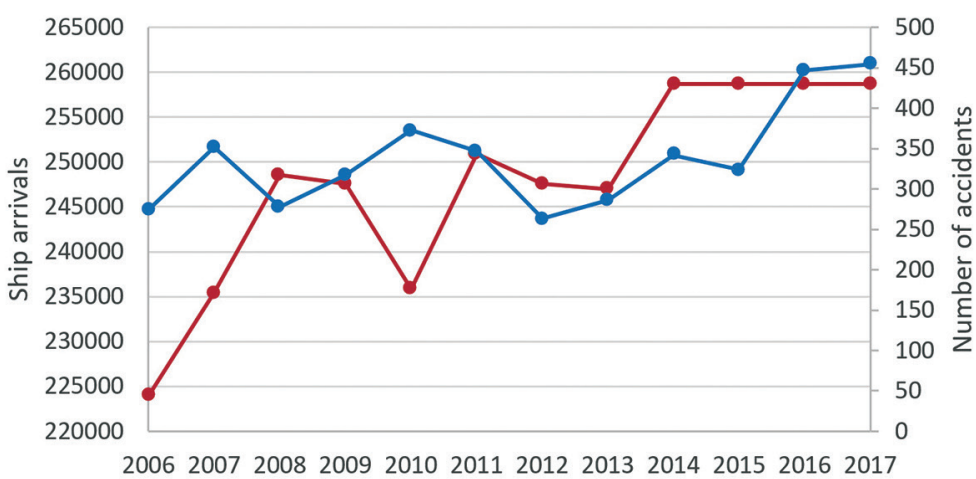

Source: Ministry of the Sea, Transport and Infrastructure, http://www.mppi.hr

Figure 3 Inter-relation between the total accidents and the total ship arrivals

Slika 3. Međuodnos ukupnih nezgoda i broja dolaska brodova

The dependence of the observed operations has been examined by using the $\mathcal{X}^{2}$ test. The produced results clearly indicate the dependence $\left(\mathcal{K}^{2}(88)=143,17 ; p<0,001\right)$ of the observed categories. This can be explained by various implementation dynamics of the Risk Control Options (RCOs) that are performed in the Republic of Croatia on a yearly basis. When referring to RCOs aimed at reduction of the risk of human life loss in Croatia, it is important to note the introduction of the Croatian Vessel Traffic Monitoring and Information System (CVTMIS). The system comprises the Automatic Identification System (AIS), maritime radar system, maritime radio-communication system, and other systems that allow the interaction with vessels and the control of navigation. The launch of the system started gradually in 2006 and by 2011 it was fully implemented, including the radar system as its integral part. There are three regional centers - Dubrovnik, Split and Rijeka. By comparing the data presented in Tables 8 and 9, it can be concluded that, after the implementation of CVTMIS, the number of maritime accidents has decreased in spite of the growing maritime traffic.

\subsection{ANALYSIS OF THE NCAF AND GCAF VALUES FOR THE REPUBLIC OF CROATIA / Analiza izračuna vrijednosti NCAF i GCAF za Republiku Hrvatsku}

When calculating the values of the NCAF and GCAF parameters for the Republic of Croatia, the following scenarios are taken into consideration:

- Value of human life 0.5 mil USD $^{1}$, and

- Three fatalities per year².

The analysis of the presented scenario indicates that the annual cost of fatalities amounts to $1.5 \mathrm{mil}$ USD. The completed CVTMIS system was implemented by the end of 2011. The total investment amounted to about 7 million US dollars. It is expected that the fatalities will be reduced from 3 per year to 3 in ten years. Taking this into consideration, the annual fatality cost is expected to drop from 1.5mil USD to 150,000USD per year, thus saving $1.35 \mathrm{mil}$ USD per year. Given the fact that the initial investment amounted to around 7mil USD, with the annual maintenance cost of around 100,000USD, the expected

${ }^{1}$ The assumed value based on the comparison with the developed countries, the estimated value of life and the life insurance claim pay-outs, and on the comparison of the assessed value of US and Croatian military staff in Afghanistan amounting to $600,000: 50,000$ USD, whereas the statistical value of human life, according to the US government, amounts to 5,000,000 USD.

${ }^{2}$ According to the statistics of SAR operations for the year2014 in the area under the jurisdiction of the National Headquarters for Search and Rescue at Sea, which are related to ships from table 7. return on investment is approximately 5.5 years.

By applying the already presented equations for the assessment of NCAF and GCAF, the following $\triangle \mathrm{R}$ values are produced:

$$
\Delta R=3 \text { fatalities } / \text { year } \cdot 250.000 \text { vessels }=0,000012
$$

Upon the implementation of CVTMIS, fatalities have been reduced to three in ten years::

$$
\Delta R=0,3 \text { fatalities } / \text { year } \cdot 250.000 \text { vessels }=0,0000012
$$

The obtained difference of the variable $\Delta R$ between the initial and final value after the introduction of the abobe described measures amounts to 0.0000108 .

The variable $\Delta B$ presents the difference between the initial cost, i.e. three fatalities per year (1.5mil USD) and three fatalities in ten years or, in other words, the amount of $1.35 \mathrm{mil}$ USD multiplied by the annual average of 250,000 vessels, and is expressed as:

$$
\Delta B=1,35 \text { milUSD } \div 250.000 \text { vessels }=5,4
$$

The investment cost of reducing the risk per vessel is presented by the variable $\Delta \mathrm{C}$. As the investment is $7 \mathrm{mil}$ USDand the amount being dividd by the average number of vessels, the resulting equation is:

$$
\Delta C=7 \text { milUSD } \div 250.000 \text { vessels }=28 U S D / \text { vessel }
$$

If the obtained values are placed in interaction, then:

$$
\begin{gathered}
N C A F=\frac{\Delta C-\Delta B}{\Delta R}=\frac{28-5,4}{0,0000108}=\frac{22,6}{0,0000108}=2,092 m_{1} \_U S D \\
G C A F=\frac{\Delta C}{\Delta R}=\frac{28}{0,0000108}=2,592 \mathrm{mil}_{-} U S D
\end{gathered}
$$

\subsection{VALUE OF THE ICAF PARAMETER FOR THE REPUBLIC OF CROATIA / Vrijednost parametra ICAF za Republiku Hrvatsku}

The calculation of the Implied Cost of Averting a Fatality(ICAF) for the Republic of Croatia requires the following data:

- $\quad \gamma-14.000$ USD/resident[15],

$\varepsilon$ - life expectancy 77.8 years[19], and

$w$ - working life 31 years [20][21]. 
Theeconomically active part of lifetime (w) in Croatia takes into account the average of 8 working hours per day, 5 working days a week, and the working life of 31 yaers. The calculation can be expressed as:

$w=\frac{31 \text { years } \cdot 8 \frac{\text { hours }}{\text { day }} \cdot 5 \frac{\text { days }}{\text { week }} \cdot 48 \frac{\text { weeks }}{\text { year }}}{77,8 \text { years } \cdot 24 \frac{\text { hours }}{\text { day }} \cdot 7 \frac{\text { days }}{\text { week }} \cdot 52 \frac{\text { weeks }}{\text { year }}}=\frac{59520}{679.660,8}=0,08757 \approx 0,1$

As it is considered that:

$$
\mathrm{ICAF}_{0}=\frac{\gamma \cdot \varepsilon}{4} \cdot \frac{1-\mathrm{w}}{\mathrm{w}}
$$

The insertion of the obtained data results in:

$$
\mathrm{ICAF}_{0}=\frac{14000 \cdot 77,8}{4} \cdot \frac{1-0,1}{0,1}=272.300 \cdot 9=2.450 .700 U S D
$$

\section{CONCLUSION / Zaključak}

Despite the continuous growth of the global maritime shipping and the world fleet, the number of fatalities in sea accidents has been dropping. From the risk analysis point of view, there is a noticeable need for hazard detection at workplace in order to assess the risk and analyse all measures and options that can be applied to reduce the risk. As for the applied Risk Control Options (RCOs), their cost effectiveness is easy to determine when material risk is observed. The matter gets more complex and challenging when trying to assess the risks to the environment and human life. The ALARP (As Low As Reasonably Practicable) principle has been introduced as a response to this issue. It implies that the cost of RCOs has to be lower than the damage caused by the incident.

In order to make the application of FSA (Formal Safety Assessment) methodology efficient, it is essential to define all hazards and measures for reducing the risk. A detailed consideration of the FSA issues allows identifying the key tools for calculating the value of human life at sea, i.e. Gross Cost of Averting a Fatality (GCAF), Net Cost of Averting a Fatality (NCAF) and Implied Cost of Averting a Fatality (ICAF). Although the International Maritime Organization (IMO) has accepted the criterion of efficiency of the applied risk prevention measures amounting to 3 million US dollars, additional RCOs must be taken into consideration as, in maritime shipping, hazards often refer to environmental damage at the same time, so that the overall damage or cost is significantly larger than the value of human life.

The figures referring to the maritime traffic and accidents in the Republic of Croatia indicate a noticeable decrease in the overall sea accidents during the period 2006 - 2013, while during the period 2014 - 2017 there was an increase in sea accidents together with an increase in ship traffic. The most evident reduction of accidents was experienced after the introduction of the Croatian Vessel Traffic Monitoring and Information System (CVTMIS) in 2011. This research used the CVTIMS implementation as a RCO, i.e. as input information for calculating GCAF and NCAF in Croatia.

None of these parameters exceeded the limit of one million US dollars during the process of calculating and obtaining their final values for the Republic of Croatia. It can be concluded that even if the obtained values were beyond the maximum limit of 3 million dollars, the RC should be taken into account as the calculation refers only to reducing the risk to human life. If the above value is augmented by the value of reducing the risk of environmental pollution, then the benefits are multiple and the cost effectiveness is obvious. As for the calculation of ICAF parameters for the Republic of Croatia, the obtained value of 2.45 million USD implies that the value of human life is lower than in the developed economies. Compared to Croatia, the value of life in the USA, according to their official parameters, amounts to 4.5 million USD. Clearly, a higher level of economic development indirectly corresponds to a higher value of the human life.

\section{REFERENCES / Literatura}

Books

[1] Kristiansen, S.: Maritime Transportation: Safety Management and Risk Analysis, Elsevier Butterworth-Heinemann, Burlington, UK, 2005.

Papers

[2] Hess, M.; Kos, S.; Njegovan. M.: Procjena i kontrola operativnih rizika na brodu u skladu s ISM pravilnikom / Assessment and control of operational risks on board in line with ISM rulebook, in: Pomorstvo, University of Rijeka - Faculty of Maritime Studies, Rijeka, 2011.

[3] Sirous, Y.: The ALARP Argument, Safe Sight Technology, Surbiton, UK, 2013. (URL: http://www.researchgate.net/profile/Sirous Yasseri/publication/274677545 The_ALARP_Argument/links/55250d7b0cf2caf1 1 bfffcbf.pdf, November, 2018.)

[4] Uğurlu, O., Yildirim, U.,Başar, E.: Analysis of grounding accidents caused by human error, Journal of Marine Science and Technology 23(5):748-760, 2015.DOI: 10.6119/JMST-015-0615-1

[5] Razali, C. S., Hamid, N. A., Mokhtar, K.: A Theoretical Review of Human Error in Maritime Accidents, Journal of Computational and Theoretical Nanoscience 22(9):2109-2112, 2016. https://doi.org/10.1166/asl.2016.7058

[6] Apostol-Mates, R., Barbu, A.: Human Error-The Main Factor in Marine Accidents, Naval Academy Scientific Bulletin, Volume XIX - 2016.

[7] Kontovas, C. A., Psaraftis, H. N.: Formal Safety Assessment: A Critical Review Marine technology 46(1):45-59, 2009.

Regulations

[8] Formal Safety Assessment, Consolidated text of the Guidelines for Formal Safety Assessment (FSA) for use in the IMO rule-making process (MSC/ Circ.1023-MEPC/Circ.392), MSC 83/INF.2, IMO, London, UK, 2007. (URL: http://research.dnv.com/skj/IMO/MSC83-INF-2.pdf, November, 2018)

[9] Formal Safety Assessment, Decision parameters including risk acceptance criteria, Submitted by Norway, MSC 72/16, IMO, London, UK, 2000. (URL: http://research.dnv.com/skj/FsaLsaBc/MSC72-16.pdf, November, 2018)

[10] Formal Safety Assessment, Possible improvements on FSA Guidelines, Submitted by Greece, MSC 82/INF.3, IMO, London, UK, 2006. (URL: http:// www.sjofartsverket.se/pages/9763/82-INF3.pdf, November, 2018)

[11] Formal Safety Assessment, Risk evaluation, International Association of Classification Societies (IACS), MSC 78/19/2, IMO, London, UK, 2004. (URL: http://www.sjofartsverket.se/upload/4003/78-19-2.pdf, November, 2018)

[12] Guidelines for Formal Safety Assessment (FSA) for Use in the IMO Rule-Making Process, MSC/Circ.1023, MEPC/Circ.392, IMO, London, UK, 2002. (URL: http://www.imo.org/en/OurWork/HumanElement/VisionPrinciplesGoals/ Documents/1023-MEPC392.pdf, November, 2018)

[13] Marine risk assessment, Offshore Technology Report 2001/063, Det Norske Veritas, Health and Safety Executive, London, UK, 2002. (URL: http://www. hse.gov.uk/research/otopdf/2001/oto01063.pdf, November, 2018)

[14] Revised Guidelines for Formal Safety Assessment (FSA) for use in the IMO rule-making process, MSC-MEPC.2/Circ.12, IMO, London, UK, 2013. (URL: http://research.dnv.com/skj/IMO/MSC-MEPC\%202_Circ\%2012\%20 FSA\%20Guidelines\%20Rev\%20III.pdf, November, 2018) https://doi. org/10.5040/9781509915781.0029 Web sites and other sources

[15] Croatian Bureau of Statistics, http://www.dzs.hr/ [accessed: 2019-01-25]

[16] Ministry of the Sea, Transport and Infrastructure, http://www.mppi. hr[accessed: 2019-01-25]

[17] Ministry of the Sea, Transport and Infrastructure, http://www.mppi.hr/ UserDocsImages/SAR\%20STAT\%201999-2008.pdf[accessed: 2019-01-25]

[18] http://www.imo.org/en/OurWork/Safety/SafetyTopics/Pages/ FormalSafetyAssessment.aspx[accessed: 2019-01-25]

[19] http://countryeconomy.com/demography/life-expectancy/croatia [accessed: 2019-01-25]

[20] http://liderpress.hr/biznis-i-politika/hrvatska/prosjecni-radni-vijek-uhrvatskoj-medu-najkracima-u-europi/[accessed: 2019-01-25]

[21] The Croatian National Bank, http://www.hnb.hr/tecajn/h311213.htm[accessed: 2019-01-25] 